\title{
Calcium Dependencies of Regulated Exocytosis in Different Endocrine Cells
}

\author{
J. DOLENŠEK ${ }^{1}$, M. SKELIN ${ }^{1}$, M. S. RUPNIK ${ }^{1,2}$ \\ ${ }^{1}$ Institute of Physiology, Faculty of Medicine, University of Maribor, Maribor, Slovenia, ${ }^{2}$ Centre \\ of Excellence for Integrated Approaches in Chemistry and Biology of Proteins (CIPKeBiP), \\ Ljubljana, Slovenia
}

Received December 6, 2010

Accepted February 17, 2011

On-line July 19, 2011

\section{Summary}

Exocytotic machinery in neuronal and endocrine tissues is sensitive to changes in intracellular $\mathrm{Ca}^{2+}$ concentration. Endocrine cell models, that are most frequently used to study the mechanisms of regulated exocytosis, are pancreatic beta cells, adrenal chromaffin cells and pituitary cells. To reliably study the $\mathrm{Ca}^{2+}$ sensitivity in endocrine cells, accurate and fast determination of $\mathrm{Ca}^{2+}$ dependence in each tested cell is required. With slow photo-release it is possible to induce ramp-like increase in intracellular $\mathrm{Ca}^{2+}$ concentration $\left(\left[\mathrm{Ca}^{2+}\right]_{\mathrm{i}}\right)$ that leads to a robust exocytotic activity. Slow increases in the $\left[\mathrm{Ca}^{2+}\right]_{\mathrm{i}}$ revealed exocytotic phases with different $\mathrm{Ca}^{2+}$ sensitivities that have been largely masked in step-like flash photo-release experiments. Strikingly, in the cells of the three described model endocrine tissues (beta, chromaffin and melanotroph cells), distinct $\mathrm{Ca}^{2+}$ sensitivity 'classes' of secretory vesicles have been observed: a highly $\mathrm{Ca}^{2+}$-sensitive, a medium $\mathrm{Ca}^{2+}$-sensitive and a low $\mathrm{Ca}^{2+}$ sensitive kinetic phase of secretory vesicle exocytosis. We discuss that a physiological modulation of a cellular activity, e.g. by activating CAMP/PKA transduction pathway, can switch the secretory vesicles between $\mathrm{Ca}^{2+}$ sensitivity classes. This significantly alters late steps in the secretory release of hormones even without utilization of an additional $\mathrm{Ca}^{2+}$ sensor protein.

\section{Key words}

Calcium sensitivity - Exocytosis - Insulin-secreting cells • Chromaffin cells $\bullet$ Melanotrophs

\section{Corresponding author}

Marjan Rupnik, University of Maribor, Slomškov trg 15, SI-2000 Maribor, Slovenia. Fax: +3862330 5853. E-mail: marjan.rupnik@uni-mb.si

\section{Introduction}

Increase in intracellular calcium concentration $\left(\left[\mathrm{Ca}^{2+}\right]_{\mathrm{i}}\right)$ is a key signal to trigger exocytosis in most neuronal and endocrine tissues. Experimentally the best described endocrine cell models to study the role of $\mathrm{Ca}^{2+}$ in the regulated exocytosis are pancreatic beta cells (Barg et al. 2001, Takahashi et al. 1997, Wan et al. 2004), adrenal chromaffin cells (Augustine and Neher 1992, Neher and Zucker 1993, Voets 2000, Voets et al. 1999) and pituitary melanotroph cells (Sedej et al. 2005). A whole range of different physiological stimuli (like glucose, acetylcholine, etc.) can trigger increase in $\left[\mathrm{Ca}^{2+}\right]_{i}$ and induce exocytosis. The exocytotic activity itself can also be further modulated by a range of physiological signals (like GLP-1, dopamine, etc).

The role of cytosolic $\mathrm{Ca}^{2+}$ has been shown to be multiple, on one hand $\mathrm{Ca}^{2+}$ is directly involved in the fusion of the secretory vesicles with plasma membrane (Katz and Miledi 1965), and on the other hand, these ions also function in the several distinct maturation steps of these secretory vesicles prior to fusion (Voets 2000). Some of these $\mathrm{Ca}^{2+}$-dependent steps in the late stages of the secretory activity have not yet been described in detail. The aforementioned biochemical maturation steps have been attempted to be separated into distinct functional states or pools using different experimental approaches to increase cytosolic $\mathrm{Ca}^{2+}$, like whole-cell dialysis, trains of depolarizing pulses or caged $\mathrm{Ca}^{2+}$ photolysis. Based on the depolarization studies it has 
been found that insulin granules (Rorsman and Renstrom 2003), similar to secretory vesicles in numerous other cell types, exist within the cell in various pools. These, so called, releasable pools of vesicles have been termed readily releasable (RRP), immediately releasable (IRP) and slowly releasable pool (SRP) (described in detail in Mears 2004, Rorsman and Renström 2003 for beta cells, in Voets 2000, Voets et al. 1999 for chromaffin cells and in Sedej et al. 2005 for melanotroph cells). Most of previous experiments did not focus on establishing $\mathrm{Ca}^{2+}$ sensitivity per se, rather focusing on distinguishing pools of vesicles upon their putative biochemical state or localisation within the cell. The biochemical maturation state and localisation were supposed to define the limiting conditions for the release of the vesicles from corresponding releasable pools. In addition, these studies largely assumed relatively low sensitivity to $\mathrm{Ca}^{2+}$, utilizing $\mathrm{Ca}^{2+}$ microdomain concept, with $\mathrm{Ca}^{2+}$ sensitive proteins on secretory vesicles facing the inner mouth of the voltage-activated $\mathrm{Ca}^{2+}$ channels (Neher and Sakaba 2008). No matter from which releasable pool they originate, vesicle exocytosis in endocrine cells, as in synapse, is managed by SNARE (soluble $N$ ethylmaleimide-sensitive factor attachment protein receptor) fusion machinery (Easom 2000, Lang 1999).

Biochemical studies suggested numerous $\mathrm{Ca}^{2+}$ sensor proteins with vast variability in their sensitivity to $\mathrm{Ca}^{2+}$. Synaptotagmins appear to be a primary $\mathrm{Ca}^{2+}$ sensor proteins, however some forms of $\mathrm{Ca}^{2+}$ dependent exocytosis may use yet unidentified sensors (Pang and Südhof 2010). Alternatively to having different synaptotagmin isoforms to cover a whole range of $\mathrm{Ca}^{2+}$ sensitivities of the secretory vesicles, we can have ways to significantly influence the $\mathrm{Ca}^{2+}$ sensitivity of a given synaptotagmin by changing the physiological context of the cell.

In previous studies few simple questions have been largely overlooked: what is the precise $\left[\mathrm{Ca}^{2+}\right]_{\mathrm{i}}$ threshold to trigger fusion of the secretory vesicles? How much do cells in different endocrine tissues differ in their $\mathrm{Ca}^{2+}$ sensitivities? And finally, can we physiologically influence the $\mathrm{Ca}^{2+}$ sensitivity within these different endocrine cells?

\section{Previous studies on $\mathrm{Ca}^{2+}$ sensitivity of secretory vesicle exocytosis}

Differences in $\mathrm{Ca}^{2+}$ sensitivities among different endocrine cells types were also readily observed in depolarization experiments where trains of depolarizing pulses were used to mimic the electrical activity and therefore physiological stimulation in different endocrine cells (Figure 1). The depolarization pulses opened voltage-activated $\mathrm{Ca}^{2+}$ channels. Subsequent influx of $\mathrm{Ca}^{2+}$ through these channels increased $\left[\mathrm{Ca}^{2+}\right]_{\mathrm{i}}$. Due to localisation of voltage-gated calcium channels at the plasma membrane, spatial $\mathrm{Ca}^{2+}$ concentration gradients should build up (Neher and Augustine 1992) to trigger $\mathrm{Ca}^{2+}$-dependent exocytosis. Such exocytotic events can be adequately measured as membrane capacitance $\left(C_{\mathrm{m}}\right)$ changes (Neher and Marty 1982) since this parameter is linearly proportional to the membrane surface area.

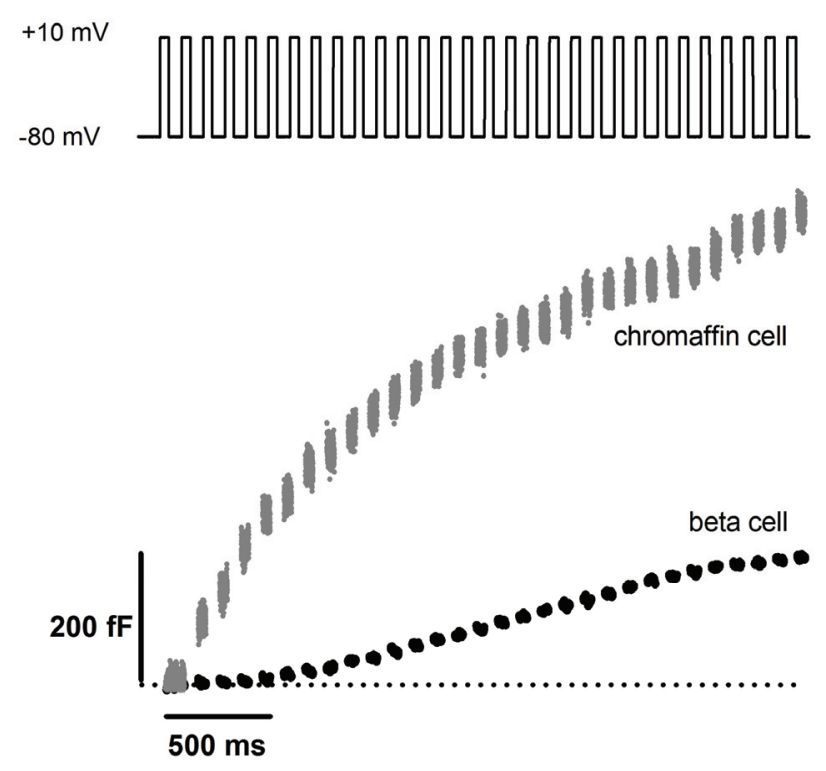

Fig. 1. A train of depolarizing pulses triggers higher $C_{m}$ response in chromaffin cells compared to beta cells. Train of depolarizations (upper panel) elicited a cumulative $C_{m}$ change (lower panel) in pancreatic beta cell (black) and chromaffin cell (gray). The train consisted of thirty $40 \mathrm{~ms}$ depolarization pulses from $-80 \mathrm{mV}$ to $+10 \mathrm{mV}$ at a frequency of $10 \mathrm{~Hz}$. Already the first depolarization pulse triggered a several times larger $C_{m}$ increase in chromaffin compared to beta cells suggesting higher sensitivity of the secretory machinery to $\mathrm{Ca}^{2+}$.

Already after the first depolarization pulse a several times larger increase in $C_{\mathrm{m}}$ has been observed in chromaffin cells compared to pancreatic beta cells (Figure 1). Chromaffin cells express a higher density of voltage-activated $\mathrm{Ca}^{2+}$ channels as beta cells; therefore a comparable influx of $\mathrm{Ca}^{2+}$ ions has not been expected. Nevertheless, this experiment may also indicate that the secretory vesicles in chromaffin cells may be more sensitive to $\mathrm{Ca}^{2+}$ than in beta cells.

A variety of depolarization protocols have been 
utilized to trigger $\mathrm{Ca}^{2+}$ regulated exocytosis (Barg et al. 2001, Barg et al. 2001, Chow et al. 1996, Ge et al. 2006, Marengo 2005, Voets et al. 1999). Lengths of the depolarization pulses varied largely in these experiments. Since majority of experiments were done on isolated cells in which significant portion of $\mathrm{Ca}^{2+}$ and $\mathrm{Na}^{+}$channels were lost due to cell isolation procedures, unphysiologically long depolarization pulses were mostly required $(500 \mathrm{~ms})$ to stimulate $\mathrm{Ca}^{2+}$-dependent exocytosis (Barg et al. 2002, Barg et al. 2001).

For depolarization pulses experiments it is difficult to determine actual values of $\left[\mathrm{Ca}^{2+}\right]_{i}$ sensed by the secretory vesicles, therefore $\mathrm{Ca}^{2+}$ sensitivity studies are not straightforward using this method. $\mathrm{Ca}^{2+}$ influx and $\mathrm{Ca}^{2+}$ concentration gradients spanning near the plasma membrane during depolarizations were reported in several model cells (Chow et al. 1994, Klingauf and Neher 1997, Neher and Augustine 1992, Rose et al. 2007). In some experiments on chromaffin cells $\left[\mathrm{Ca}^{2+}\right]_{\mathrm{i}}$ was back-calculated from $C_{\mathrm{m}}$ and amperometry data assuming the same kinetic dependence of secretion upon $\mathrm{Ca}^{2+}$ concentration as obtained from experiments where $\mathrm{Ca}^{2+}$ has been manipulated by instantaneous release from buffer cages (Chow et al. 1994). The calculated $\left[\mathrm{Ca}^{2+}\right]_{\mathrm{i}}$ values during brief depolarizations have been as high as $10 \mu \mathrm{M}$ close to the plasma membrane. This relatively high $\left[\mathrm{Ca}^{2+}\right]_{\mathrm{i}}$ indicated that the $\mathrm{Ca}^{2+}$ sensitivity may be low affinity but no more precise information could be elucidated from these experiments. More recently a confocal imaging approach has been used to quantify $\mathrm{Ca}^{2+}$ gradients during depolarization induced $C_{\mathrm{m}}$ changes in chromaffin cells (Marengo 2005). In this study a lower peak $\left[\mathrm{Ca}^{2+}\right]_{\mathrm{i}}$ has been determined $(\sim 1 \mu \mathrm{M})$, with an even lower threshold $\left[\mathrm{Ca}^{2+}\right]_{\mathrm{i}}(<1 \mu \mathrm{M})$ for $C_{\mathrm{m}}$ response indicating high sensitivity of the secretory machinery.

These latter results are in the agreement with earlier experiments studying $\mathrm{Ca}^{2+}$ sensitivities of the vesicle exocytosis, utilizing whole-cell patch-clamp dialysis of intracellular solution with different concentrations of $\mathrm{Ca}^{2+}$ to stimulate regulated exocytosis (Augustine and Neher 1992, Rupnik et al. 1995). In this manner the $\left[\mathrm{Ca}^{2+}\right]_{i}$ was raised slowly (tens of seconds) as defined by the limitation in the diffusion between the patch pipette and the cell interior. The obtained $\mathrm{Ca}^{2+}$ dependency curves indicated that endocrine cells were very sensitive to $\mathrm{Ca}^{2+}$. Triggering $\mathrm{Ca}^{2+}$ concentration has been reported to be $0.2 \mu \mathrm{M}$ in chromaffin cells. However, the maximal rate of fusion has been reached no sooner than two orders of magnitude higher $\left[\mathrm{Ca}^{2+}\right]_{\mathrm{i}}(10 \mu \mathrm{M})$ (Augustine and Neher 1992). Similar values in high $\left[\mathrm{Cl}^{-}\right]_{\mathrm{i}}$ conditions have been reported for both triggering and saturating $\left[\mathrm{Ca}^{2+}\right]_{\mathrm{i}}$ in rat melanotrophs using the same approach (Rupnik et al. 1995). In addition, a low threshold for secretion $(<1 \mu \mathrm{M})$ was observed in digitonin permealized chromaffin cells (Teraoka et al. 1993). On the other hand, triggering $\left[\mathrm{Ca}^{2+}\right]_{i}$ has been reported to be significantly higher at $2 \mu \mathrm{M}$ in beta cells (Barg et al. 2001).

\section{Photo-release of caged $\mathrm{Ca}^{2+}$ compounds}

The application of photo-release of caged $\mathrm{Ca}^{2+}$ compounds (e.g. NP-EGTA) has immensely contributed to our understanding of $\mathrm{Ca}^{2+}$-dependent exocytosis (Neher and Zucker 1993). When cell is dialyzed with the intracellular solution containing $\mathrm{Ca}^{2+}$-NP-EGTA, the subsequent UV illumination releases $\mathrm{Ca}^{2+}$ ions from the buffer cage. There are major advantages in using photorelease approach. Photo-release of caged $\mathrm{Ca}^{2+}$ increases $\left[\mathrm{Ca}^{2+}\right]_{\mathrm{i}}$ uniformly throughout the cell. This avoids the problem of loss of $\mathrm{Ca}^{2+}$ and $\mathrm{Na}^{+}$channels during cell isolation procedures or up-regulation of protein expression during cell culturing. Furthermore, the photorelease approach bypasses any modulatory effects that act on electrical excitability and $\mathrm{Ca}^{2+}$ influx (Neher 2006). In pancreatic beta cells at least one third of cells did not show voltage-dependent inward current during the voltage protocol (Speier and Rupnik 2003).

So far most widely used form of photo-release was the instant uncaging of $\mathrm{Ca}^{2+}$ ions by strong flash of UV light (flash photolysis). This approach has been applied to several secretory cells including pancreatic beta cells (Ge et al. 2006, Takahashi et al. 1997, Wan et al. 2004), chromaffin cells (Heinemann et al. 1994, Neher and Zucker 1993, Voets 2000) and melanotrophs (Rupnik et al. 2000). Most of these experiments in endocrine tissues were done using flash photolysis of $\mathrm{Ca}^{2+}$ to several tens of $\mu \mathrm{M}$ (Chow et al. 1994, Ge et al. 2006, Neher and Zucker 1993, Takahashi et al. 1997, Voets 2000, Wan et al. 2004). These relatively high $\mathrm{Ca}^{2+}$ concentrations were used in an attempt to completely deplete releasable pools of vesicles and study the kinetics of their release.

In some of the photo-release studies attempts to determine threshold $\mathrm{Ca}^{2+}$ concentration have been made, however the data reported have not been consistent. In adrenal slices the triggering concentration $>3 \mu \mathrm{M}$ was 
A

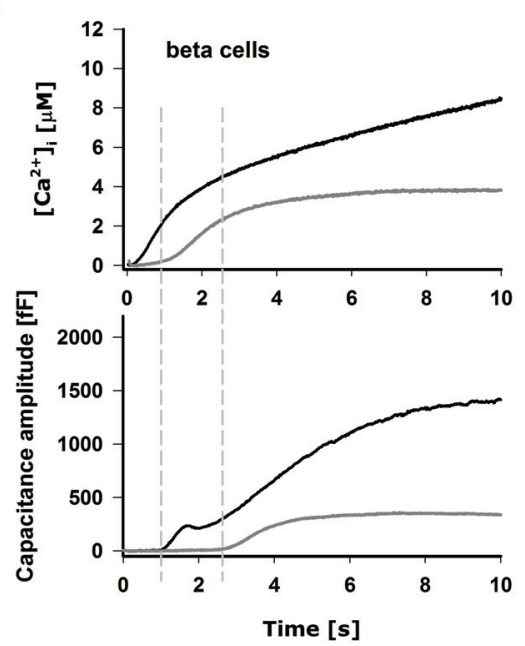

B

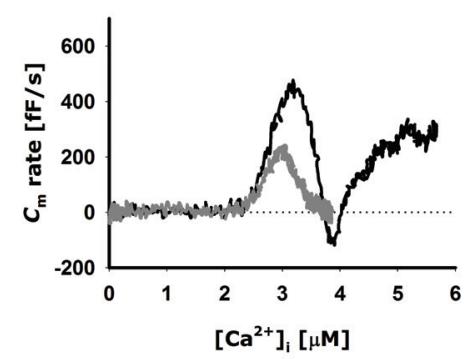

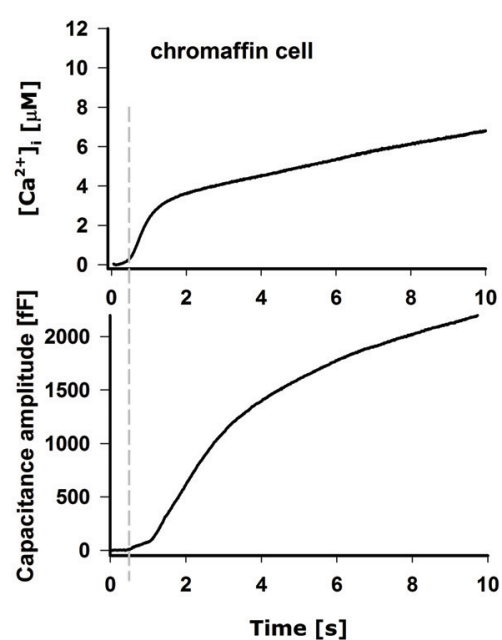
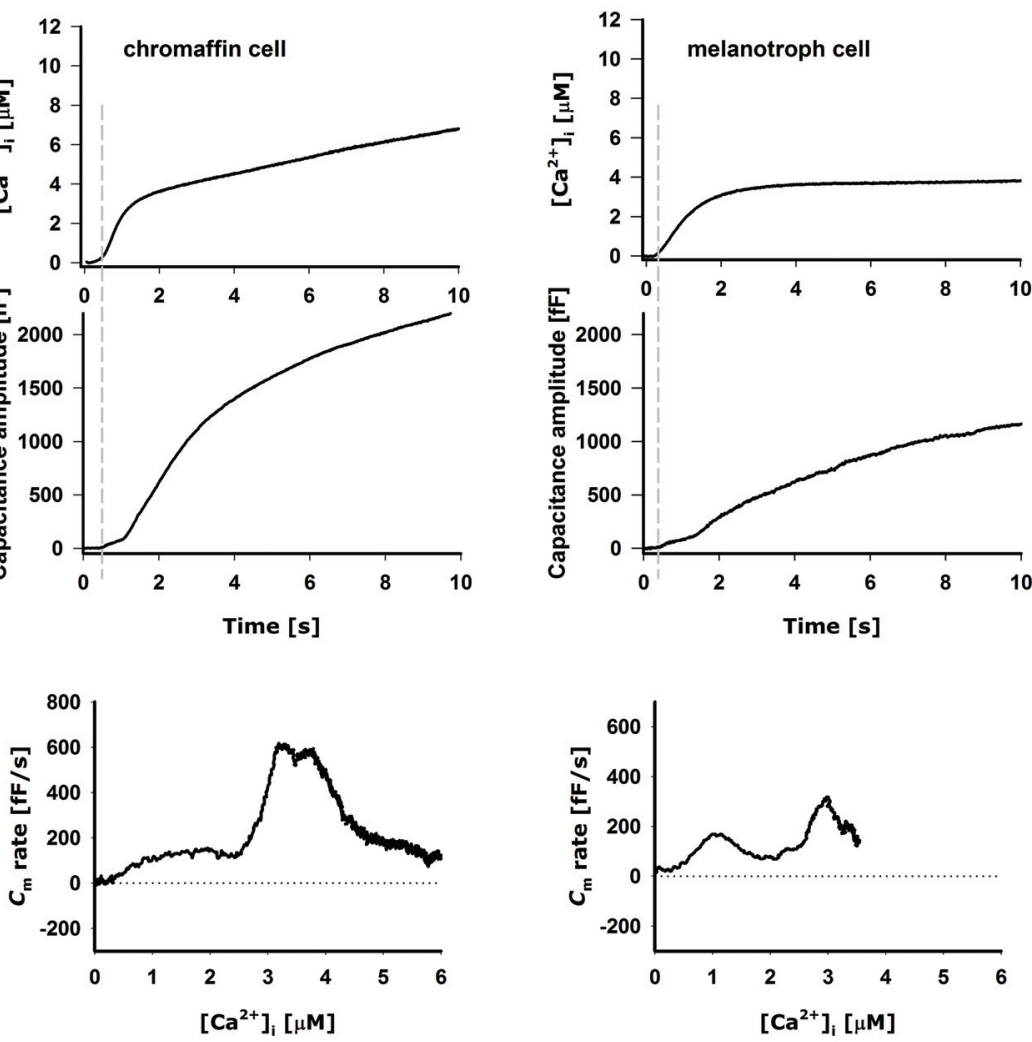

Fig. 2. Slow photo-release of Ca-NP-EGTA induced a several kinetic phases of $C_{m}$ increase in a beta cell, a chromaffin cell and a melanotroph cell. (A) Slow photo-release of caged $\mathrm{Ca}^{2+}$ produced a ramp-like increase in intracellular calcium concentration $\left(\left[\mathrm{Ca}^{2+}\right]_{\mathrm{i}}\right)$ (upper panels) in beta cell (first column), chromaffin cell (middle column) and melanotroph cell (right column). After reaching the triggering $\left[\mathrm{Ca}^{2+}\right]_{\mathrm{i}}\left(\mathrm{Ca}_{\mathrm{tr}}\right.$ - dashed lines) mostly a biphasic membrane capacitance $\left(C_{\mathrm{m}}\right)$ was triggered (lower panels) $(\mathbf{B})$ Rate of $\mathrm{C}_{\mathrm{m}}$ change depended on $\left[\mathrm{Ca}^{2+}\right]_{\mathrm{i}}$. In beta cells the two phases of $\mathrm{C}_{\mathrm{m}}$ response were triggered at $2.6 \mu \mathrm{M}$ and $4.2 \mu \mathrm{M}$ calcium concentrations, respectively. In chromaffin and melanotroph cell a low $\mathrm{Ca}^{2+}$ triggered kinetic phase is observed with triggering $\mathrm{Ca}^{2+}$ concentration $\sim 0.5 \mu \mathrm{M}$. Representative responses of cells for each endocrine tissue are shown.

reported (Voets 2000) which is one order of magnitude higher than reported from dialysis experiments (Augustine and Neher 1992). In pancreatic beta cells even results obtained with the same experimental design are confusing. In some studies exocytosis was triggered at $\left[\mathrm{Ca}^{2+}\right]_{\mathrm{i}}$ as low as 2-3 $\mu \mathrm{M}$ (Barg et al. 2001, Wan et al. 2004) while in others more that $10 \mu \mathrm{M}$ of $\mathrm{Ca}^{2+}$ was needed to evoke $C_{\mathrm{m}}$ change (Barg et al. 2001). The aforementioned inconsistencies strongly suggest that the flash photolysis approach is not a method of choice to study the $\mathrm{Ca}^{2+}$ sensitivity of secretory machinery.

Based on the results of flash photolysis experiments on beta cells, two distinct secretory vesicle populations with different $\mathrm{Ca}^{2+}$ sensitivities were suggested (Barg and Rorsman 2004, Wan et al. 2004, Yang and Gillis 2004). The authors suggested a secretory mechanism where granules with low-affinity $\mathrm{Ca}^{2+}$ sensor would need to be associated with voltage-gated $\mathrm{Ca}^{2+}$ channels while granules with high-affinity $\mathrm{Ca}^{2+}$ sensor would be able to undergo exocytosis after global elevation of $\left[\mathrm{Ca}^{2+}\right]_{\mathrm{i}}$. However, whether microdomains are really necessary for the release of secretory vesicles at low $\mathrm{Ca}^{2+}$ concentrations in all endocrine models still needs to be confirmed.

\section{Slow photo-release - a $\mathrm{Ca}^{2+}$ ramp based measurement of $\mathrm{Ca}^{2+}$ sensitivity of secretory vesicle exocytosis}

To reliably study $\mathrm{Ca}^{2+}$ sensitivity of the regulated exocytosis, accurate and fast determination of the triggering $\left[\mathrm{Ca}^{2+}\right]_{\mathrm{i}}$ and $\mathrm{Ca}^{2+}$ dependence in each tested cell is required. With slow photo-release of caged $\mathrm{Ca}^{2+}$ it is possible to induce ramp-like increase in $\left[\mathrm{Ca}^{2+}\right]_{i}$ that leads to a robust secretory activity (Liu et al. 2008, Paulmann et al. 2009). Gradually increasing $\left[\mathrm{Ca}^{2+}\right]_{\mathrm{i}}$ inside the cell provides a test with a continuous $\left[\mathrm{Ca}^{2+}\right]_{i}$ levels within a single experiment. In contrast, in the flash photolysis experiments only a single value of $\mathrm{Ca}^{2+}$ concentration (usually maximal value) is sampled per 
cell. Slowly changing $\left[\mathrm{Ca}^{2+}\right]_{\mathrm{i}}$ can reveal the triggering of several exocytotic kinetic phases with different $\mathrm{Ca}^{2+}$ sensitivities that may be masked in flash photolysis experiments, where a rapid and large jump in $\left[\mathrm{Ca}^{2+}\right]_{\mathrm{i}}$ would trigger all the kinetic phases simultaneously, preventing their discrimination.

The slow photo-release of caged $\mathrm{Ca}^{2+}$ has been applied in three different mouse endocrine cell types: beta cells from pancreatic islets of Langerhans, chromaffin cells from adrenal medulla and melanotroph cells from the intermediate lobe of the pituitary gland (Figure 2). During the $\mathrm{Ca}^{2+}$ ramp the $\left[\mathrm{Ca}^{2+}\right]_{i}$ gradually increased from the resting levels to 3-10 $\mu \mathrm{M}$ in approximately ten seconds. In addition to $\left[\mathrm{Ca}^{2+}\right]_{\mathrm{i}}$ we simultaneously measured net change in $C_{\mathrm{m}}$ (method described in detail in Skelin and Rupnik, 2011). When $\left[\mathrm{Ca}^{2+}\right]_{i}$ reached a threshold level, typically a distinguishable $C_{\mathrm{m}}$ change has been observed. At lower $\left[\mathrm{Ca}^{2+}\right]_{\mathrm{i}}$, only one kinetic phase has been observed (Figure $2 \mathrm{~A})$. However, during the $\mathrm{Ca}^{2+}$ ramps to higher $\left[\mathrm{Ca}^{2+}\right]_{\text {, two }}$ separate kinetic exocytotic components have been typically recorded. We named them first and second kinetic phase. For the first kinetic phase of exocytosis the time derivatives for the $C_{\mathrm{m}}$ traces $\left(C_{\mathrm{m}}\right.$ rate) reached a maximum value after which the change in $C_{\mathrm{m}}$ rate either decreased or, sometimes and typically only in isolated cells, even endocytosis occurred. This indicates that the ramp change in $\left[\mathrm{Ca}^{2+}\right]_{\mathrm{i}}$ was slow enough to mainly deplete the most $\mathrm{Ca}^{2+}$ sensitive phase that was activated at triggering $\left[\mathrm{Ca}^{2+}\right]_{\mathrm{i}}$. Further increasing $\left[\mathrm{Ca}^{2+}\right]_{\mathrm{i}}$ during the $\mathrm{Ca}^{2+}$ ramp activated a distinct $C_{\mathrm{m}}$ change.

\section{Separation of exocytotic kinetic phases}

Separation of exocytotic kinetic phases with different $\mathrm{Ca}^{2+}$ sensitivities can be readily observed when $C_{\mathrm{m}}$ rate is plotted against the $\left[\mathrm{Ca}^{2+}\right]_{\mathrm{i}}$ values obtained with the $\mathrm{Ca}^{2+}$ ramp. Rate of secretion is sensitive to $\left[\mathrm{Ca}^{2+}\right]_{\mathrm{i}}$, accelerating in several orders of magnitude as concentration is elevated - as also previously reported (Augustine and Neher 1992). The rate of secretion should provide the better indicator of the actual affinity of the exocytotic apparatus for $\left[\mathrm{Ca}^{2+}\right]_{\mathrm{i}}$ since the total amount of $C_{\mathrm{m}}$ may be limited by the total number of vesicles available for exocytosis.

Detailed analysis of the obtained $\mathrm{Ca}^{2+}$ sensitivities revealed that the initial level of $\left[\mathrm{Ca}^{2+}\right]_{i}\left(\mathrm{Ca}_{\mathrm{tr}}\right)$ to trigger the first kinetic phase of $C_{\mathrm{m}}$ increase was on average $2.6 \mu \mathrm{M}, 0.4 \mu \mathrm{M}$ and $0.4 \mu \mathrm{M}$ in beta cells, chromaffin cells and melanotroph cells, respectively. The value of $\mathrm{Ca}_{\mathrm{tr}}$ has been typical and highly reproducible for each cell type. For beta cells (Wan et al. 2004) and chromaffin cells (Liu et al. 2008) this result is in accordance with previously published data. The maximal rate during the first kinetic phase was $325 \pm 40 \mathrm{fF} / \mathrm{s}$, $243 \pm 31 \mathrm{fF} / \mathrm{s}$ and $271 \pm 110 \mathrm{fF} / \mathrm{s}$, respectively. For beta cells the maximal rate during the first phase was comparable with the results obtained from rat islets in pancreatic slices where depolarization was used to trigger exocytosis (Rose et al. 2007). The rate of secretion was few times larger in mouse adrenal slice preparation compared to respective $\left[\mathrm{Ca}^{2+}\right]_{i}$ in isolated bovine chromaffin cells (Augustine and Neher 1992, Heinemann et al. 1994). However, in melanotroph cell the maximal rate of the first kinetic phase was slower compared to the one determined using depolarization pulses (Sedej et al. 2005).

The rate of vesicle fusion during the first kinetic phase may also be expressed as number of large densecore vesicles (LDCV) per second based on average LCDV size (Rorsman and Renstrom 2003, Thomas et al. 1993). The observed rates of $C_{\mathrm{m}}$ change ( $90 \mathrm{LCDVs}$ per second) were in accordance with previously published data in beta cells (Neher and Sakaba 2008). However, pancreatic beta cells were reported to possess two distinct types of secretory vesicles, synaptic-like microvesicles (SLMV) and large dense core vesicles (LDCV), both of which undergo calcium-dependent exocytosis (Takahashi et al. 1997, Thomas-Reetz and De Camilli 1994). There is an indication that uncaging of $\mathrm{Ca}^{2+}$ released both types of vesicles (Hatakeyama et al. 2007). Therefore we preferred to express the rate of the release in $\mathrm{fF}$ per second to avoid unresolved dilemma regarding the involvement of SLMV in the regulated exocytotic.

Interestingly, in chromaffin cells maximal rates of fusion were well correlated when comparing flash photolysis experiments (Heinemann et al. 1994) and $\mathrm{Ca}^{2+}$ dialysis experiments (Augustine and Neher 1992) despite the fact that responses were obtained on different time scales (tens of miliseconds and seconds, respectively). The reason may be that both were performed on single isolated chromaffin cells. On the other hand, the photolysis experiments on chromaffin cells in adrenal slices provided several times larger $C_{\mathrm{m}}$ rate. Cell dissociation has been found to disturb some cell functions as demonstrated in adrenal chromaffin cells (Moser and Neher 1997), pituitary melanotrophs (Sedej et al. 2005) and rodent beta cells (Speier and Rupnik 2003). In slice preparation local cell-cell contacts as well as the cell 
architecture are preserved therefore providing a more physiological preparation. However, not all the functions seem to be perturbed since we did not observe any difference in $\mathrm{Ca}^{2+}$ sensitivity of the secretory machinery in pancreatic beta cells comparing cells in tissue slices to those isolated into cell culture (Skelin and Rupnik 2011). In beta cells the amplitude of the first phase, representing a number of fused vesicles, was $310 \pm 37 \mathrm{fF}$. Similar number of secretory vesicles has been found also in isolated beta cells (Barg et al. 2001, Takahashi et al. 1997, Wan et al. 2004).

\section{Second kinetic phase of the exocytotic response}

Determining the triggering $\mathrm{Ca}^{2+}$ concentration for the second phase of the biphasic response is a problem inherent to the whole-cell patch-clamp based approach to measure $C_{\mathrm{m}}$. During the $\mathrm{Ca}^{2+}$ ramp the more sensitive kinetic phases would likely mask the onset of the less $\mathrm{Ca}^{2+}$-sensitive phases. In this way the triggering concentration for the second kinetic phase would most likely be overestimated. In an attempt to overcome the shortcomings of the $C_{\mathrm{m}}$ measurement we carefully monitored other cellular parameters that may be influenced by the fusion of the secretory vesicles. As shown in Figure 3, slow photo-release of caged $\mathrm{Ca}^{2+}$ triggered, besides $C_{\mathrm{m}}$ change, also an inward current with two distinguishable phases. The first issue regarding these currents in all three tested cell types is that the inward current does not closely follow the time course of the change in $\left[\mathrm{Ca}^{2+}\right]$. The time course of any current that would merely depend on $\left[\mathrm{Ca}^{2+}\right]_{\mathrm{i}}$ should mirror the time course of a slow $\mathrm{Ca}^{2+}$ ramp. Such $\mathrm{Ca}^{2+}$-dependent currents have been previously described in beta cells and pituitary cells, however they were, at least in beta cells, outward at the holding potential of $-80 \mathrm{mV}$ (Gopel et al. 1999). An alternative explanation for our observation is that the secretory vesicles carry ion channels that, after fusion, add to the resting membrane current. This, in fact, may hold true for the second kinetic phase of the secretory activity in beta cells as well as for both kinetic phases in chromaffin cell and melanotrophs (Figure 3). Therefore, this change in the whole cell membrane current could be used to distinguish the onset of fusion of the secretory vesicles belonging to the second kinetic phase and to assess its triggering $\mathrm{Ca}^{2+}$ concentration. Triggering $\left[\mathrm{Ca}^{2+}\right]$ for the second kinetic phase of secretion was therefore $4.2 \pm 0.2 \mu \mathrm{M}, \quad 2.6 \pm 0.1 \mu \mathrm{M}$,
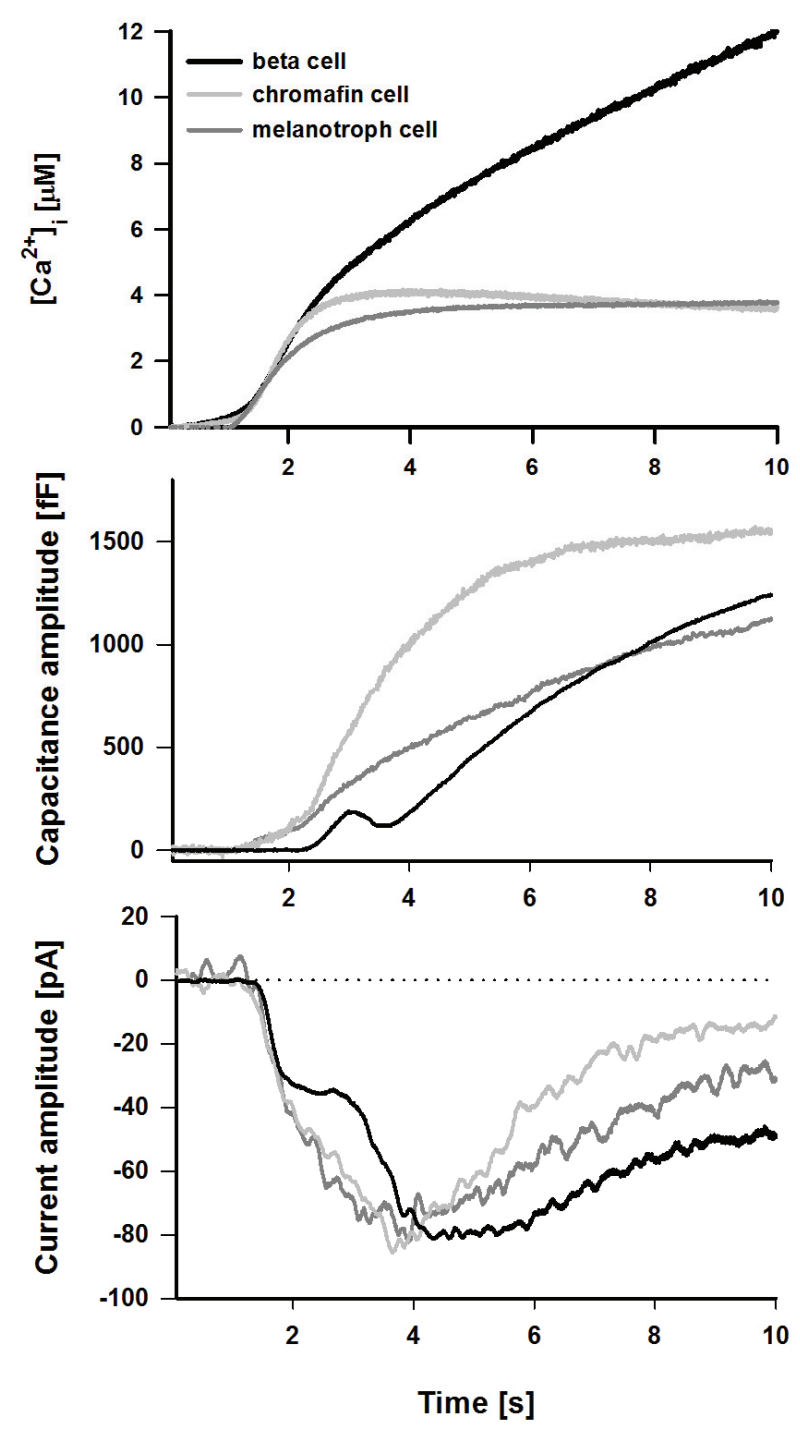

Fig. 3. Slow $\mathrm{Ca}^{2+}$ ramp triggered a biphasic increase in $C_{\mathrm{m}}$ and biphasic inward current change. Increase in $\left[\mathrm{Ca}^{2+}\right]_{\mathrm{i}}$ (upper panel) triggered a biphasic $C_{m}$ change (middle panel) and a biphasic inward current change $\left(I_{m}\right)$ in beta cell, chromaffin cell and melanotroph cell. In the latter two the first phase of $I_{\mathrm{m}}$ change was triggered simultaneously with the first kinetic phase of $C_{m}$ change. In contrast, in beta cell the first phase of $I_{\mathrm{m}}$ change was triggered at $\left[\mathrm{Ca}^{2+}\right]_{i}$ which is $2 \mu \mathrm{M}$ lower than $\left[\mathrm{Ca}^{2+}\right]_{i}$ at which the first kinetic phase of $C_{\mathrm{m}}$ was triggered. The second kinetic phase of $I_{m}$ change was triggered simultaneously with the second kinetic phase of $C_{m}$ change in all three different endocrine cells. Representative responses of cells for each endocine tissues are shown.

$1.8 \pm 0.1 \mu \mathrm{M}$ in beta cells, chromaffin cells and melanotroph cells, respectively.

However, a puzzle remained regarding the inward current triggered by $\mathrm{Ca}^{2+}$ that has not been associated with the $C_{\mathrm{m}}$ change (Figure 3 ). In beta cells only, the whole-cell current observed during stimulation with $\mathrm{Ca}^{2+}$ ramp occurred before the onset of $C_{\mathrm{m}}$ change. The first phase of $I_{\mathrm{m}}$ change was triggered at $0.5 \mu \mathrm{M}$ 
$\left[\mathrm{Ca}^{2+}\right]_{\mathrm{i}}$ (almost $2 \mu \mathrm{M}$ lower than $\left[\mathrm{Ca}^{2+}\right]_{\mathrm{i}}$ triggering $C_{\mathrm{m}}$ change). One possible explanation is that the $I_{\mathrm{m}}$ current represents a current through the fusion pore. Such microscopic fusion pore conductances can coincide with the corresponding changes in $C_{\mathrm{m}}$ (Vardjan et al. 2007). It is possible to detect also fusion pore related conductance events that do not have a simultaneous $C_{\mathrm{m}}$ change, due to the fact that the fusion pore is still too tight to support the measurement of the $C_{\mathrm{m}}$ change related to this fused vesicle. This fact would also be supported by an observation that $C_{\mathrm{m}}$ measurements miss some of the exocytotic events that could be picked up by simultaneous amperometry (Oberhauser et al. 1996)

At a triggering $\left[\mathrm{Ca}^{2+}\right]_{i}$, a stable fusion pore complex could be formed but the $\left[\mathrm{Ca}^{2+}\right]_{i}$ would not be sufficient to support the more complete fusion of the secretory vesicle. Interestingly, the fusion pore stability can be physiologically modulated. Stimulation of cAMP/PKA transduction pathway in beta cells resulted in the $C_{\mathrm{m}}$ change that appeared simultaneously with the first phase of $I_{\mathrm{m}}$ change (see below; Skelin and Rupnik 2011). It is plausible that the simultaneous onset of both $C_{\mathrm{m}}$ and $I_{\mathrm{m}}$ changes in chromaffin and melanotroph cells shows a higher level of the cAMP/PKA transduction pathway activation in these cell types. We suggest that so far unknown cAMP/PKA dependent process has the ability to destabilize the tight form of the fusion pore thereby fully fusing secretory vesicles with the plasma membrane at significantly lower $\left[\mathrm{Ca}^{2+}\right]_{\mathrm{i}}$.

\section{$\mathrm{Ca}^{2+}$ sensitivity 'classes' in different endocrine cells}

In the three model endocrine cells tested by the slow $\mathrm{Ca}^{2+}$ ramps, three distinct $\mathrm{Ca}^{2+}$ sensitivity 'classes' were observed (Figure 4): a highly $\mathrm{Ca}^{2+}$-sensitive (triggering $\left[\mathrm{Ca}^{2+}\right]_{\mathrm{i}}$ around $\sim 0.5 \mu \mathrm{M}$ ), a medium $\mathrm{Ca}^{2+}$ sensitive (triggering $\left[\mathrm{Ca}^{2+}\right]_{\mathrm{i}}$ around 2-3 $\mu \mathrm{M}$ ) and a low $\mathrm{Ca}^{2+}$-sensitive (triggering $\left[\mathrm{Ca}^{2+}\right]_{\mathrm{i}}$ around $4-5 \mu \mathrm{M}$ ) kinetic phases of exocytosis. Mouse chromaffin cells and melanotroph cells show expression of both the highly and medium $\mathrm{Ca}^{2+}$-sensitive phases, on the other hand beta cells at low cAMP availability have only the two less sensitive kinetic phases. Previous studies in beta cells did report a high $\mathrm{Ca}^{2+}$ sensitivity (Barg et al. 2001, Ge et al. 2006, Okazaki et al. 1994, Wan et al. 2004, Yang and Gillis 2004, Yaseen et al. 1982). The secretory vesicles with such a low $\mathrm{Ca}^{2+}$ sensitivity usually produces a very small change in $C_{\mathrm{m}}$ amplitude $(<20 \mathrm{fF})$ in beta cells.

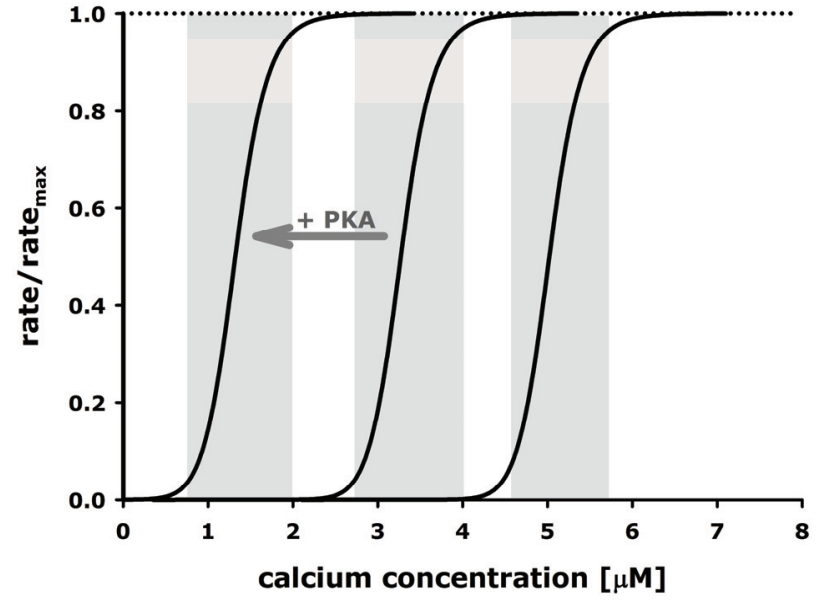

Fig. 4. A model describing $\mathrm{Ca}^{2+}$ sensitivity 'classes' in the endocrine cells. Based on triggering $\left[\mathrm{Ca}^{2+}\right]_{\mathrm{i}}$, in beta cells, chromaffin cells and melanotrophs, we propose a model consisting of three distinct 'classes' of $\mathrm{Ca}^{2+}$ sensitivities. A highly $\mathrm{Ca}^{2+}$-sensitive (triggering $\left[\mathrm{Ca}^{2+}\right]$ around $\sim 0.5 \mu \mathrm{M}$, left trace), a medium $\mathrm{Ca}^{2+}$-sensitive (triggering $\left[\mathrm{Ca}^{2+}\right]$ around 2-3 $\mu \mathrm{M}$, middle trace) and a low $\mathrm{Ca}^{2+}$-sensitive (triggering $\left[\mathrm{Ca}^{2+}\right]$ 4-5 $\mu \mathrm{M}$, right trace) kinetic phases of exocytosis. A physiological stimulation, like activation of CAMP/PKA transduction pathway transits medium- to highly $\mathrm{Ca}^{2+}$ sensitive kinetic phase in beta cells. Rates of $C_{\mathrm{m}}$ changes are depicted relative to the maximal rate.

Furthermore only a fraction of tested beta cells possessed such sensitivity (Ge et al. 2006, Wan et al. 2004). In most flash photolysis experiments this phase has been overlooked when $\left[\mathrm{Ca}^{2+}\right]_{i}$ has been instantly elevated to high $(>10 \mu \mathrm{M})\left[\mathrm{Ca}^{2+}\right]_{i}$ values, the less sensitive but larger in amplitude kinetic phases masked the more $\mathrm{Ca}^{2+}$ sensitive phases.

In beta cells specific activation of cAMP/PKA transduction pathway (by addition of cAMP or by direct activation of PKA) facilitated the expression of the high $\mathrm{Ca}^{2+}$-sensitivity kinetic phase (Skelin and Rupnik 2011). The fusion of the vesicles that has been triggered at $2.6 \mu \mathrm{M}\left[\mathrm{Ca}^{2+}\right]_{\mathrm{i}}$ was in high cAMP condition triggered at $\sim 0.5 \mu \mathrm{M}$, shifting their sensitivity 'class' to the highly $\mathrm{Ca}^{2+}$-sensitive kinetic phase (Figure 4). Modulation of the high $\mathrm{Ca}^{2+}$-sensitive phase by cAMP was observed also in the flash photolysis experiments (Wan et al. 2004). Since the cAMP is one of the major physiological modulators in intracellular signalling pathways, such a shift in the $\mathrm{Ca}^{2+}$ sensitivity represents a way to modulate the level of exocytosis. This would significantly influence the release of hormones, like insulin. Modulation of secretory activity by different physiological stimuli (e.g. GLP-1) increasing cAMP levels in the beta cells could act through the sensitization of the secretory vesicles to $\mathrm{Ca}^{2+}$. Such modulation of the $\mathrm{Ca}^{2+}$ sensitivity by GLP-1 could 
also help us understand the cellular mechanism underlying the treatment of a diabetic organism, enhancing the availability of insulin. Further experiments are underway to assess the physiological modulation of the fusion pore stability and shifts between the $\mathrm{Ca}^{2+}$ sensitivity classes. In future, we might not discover new
$\mathrm{Ca}^{2+}$ sensitive proteins, but understand that known players, like synaptotagmins, can operate differently depending on physiological context.

\section{Conflict of Interest}

There is no conflict of interest.

\section{References}

AUGUSTINE GJ, NEHER E: Calcium requirements for secretion in bovine chromaffin cells. $J$ Physiol 450: 247-271, 1992.

BARG S, ELIASSON L, RENSTROM E, RORSMAN P: A subset of 50 secretory granules in close contact with L-type $\mathrm{Ca}^{2+}$ channels accounts for first-phase insulin secretion in mouse beta-cells. Diabetes 51 (Suppl 1): 74-82, 2002.

BARG S, HUANG R, ELIASSON L, NELSON DJ, OBERMULLER S, RORSMAN P, THEVENOD F, RENSTROM E: Priming of insulin granules for exocytosis by granular $\mathrm{Cl}^{-}$uptake and acidification. $J$ Cell Sci 114: 2145-2154, 2001.

BARG S, MA X, ELIASSON L, GALVANOVSKIS J, GÖPEL SO, OBERMÜLLER S, PLATZER J, RENSTRÖM E, TRUS M, ATLAS D, STRIESSNIG J, RORSMAN P: Fast exocytosis with few $\mathrm{Ca}^{2+}$ channels in insulinsecreting mouse pancreatic B cells. Biophys J 81: 3308-3323, 2001.

BARG S, RORSMAN P: Insulin secretion: a high-affinity $\mathrm{Ca}^{2+}$ sensor after all? J Gen Physiol 124: 623-625, 2004.

CHOW RH, KLINGAUF J, HEINEMANN C, ZUCKER RS, NEHER E: Mechanisms determining the time course of secretion in neuroendocrine cells Neuron 16: 369-376, 1996.

CHOW RH, KLINGAUF J, NEHER E: Time course of $\mathrm{Ca}^{2+}$ concentration triggering exocytosis in neuroendocrine cells. Proc Natl Acad Sci U S A 91: 12765-12769, 1994.

EASOM RA: [beta]-granule transport and exocytosis. Semin Cell Dev Biol 11: 253-266, 2000.

GE Q, DONG YM, HU ZT, WU ZX, XU T: Characteristics of $\mathrm{Ca}^{2+}$-exocytosis coupling in isolated mouse pancreatic $\beta$ cells. Acta Pharmacologica Sinica 27: 933-938, 2006.

GOPEL SO, KANNO T, BARG S, ELIASSON L, GALVANOVSKIS J, RENSTROM E, RORSMAN P: Activation of $\mathrm{Ca}(2+)$-dependent $\mathrm{K}(+)$ channels contributes to rhythmic firing of action potentials in mouse pancreatic beta cells. J Gen Physiol 114: 759-770, 1999.

HATAKEYAMA H, TAKAHASHI N, KISHIMOTO T, NEMOTO T, KASAI H: Two cAMP-dependent pathways differentially regulate exocytosis of large dense-core and small vesicles in mouse beta-cells. $J$ Physiol $\mathbf{5 8 2}$ (Pt 3): 1087-1098, 2007.

HEINEMANN C, CHOW RH, NEHER E, ZUCKER RS: Kinetics of the secretory response in bovine chromaffin cells following flash-photolysis of caged $\mathrm{Ca}^{2+}$. Biophys $J$ 67: 2546-2557, 1994.

KATZ B, MILEDI R: The effect of calcium on acetylcholine release from motor nerve terminals. Proc R Soc Lond B Biol Sci 161: 496-503, 1965.

KLINGAUF J, NEHER E: Modeling buffered $\mathrm{Ca}^{2+}$ diffusion near the membrane: implications for secretion in neuroendocrine cells. Biophys J 72: 674-690, 1997.

LANG J: Molecular mechanisms and regulation of insulin exocytosis as a paradigm of endocrine secretion. Eur $J$ Biochem 259: 3-17, 1999.

LIU Y, SCHIRRA C, STEVENS DR, MATTI U, SPEIDEL D, HOF D, BRUNS D, BROSE N, RETTIG J: CAPS facilitates filling of the rapidly releasable pool of large dense-core vesicles. $J$ Neurosci 28: 5594-5601, 2008.

MARENGO FD: Calcium gradients and exocytosis in bovine adrenal chromaffin cells. Cell Calcium 38: 87-99, 2005.

MEARS D: Regulation of insulin secretion in islets of Langerhans by Ca(2+) channels. J Membr Biol 200: 57-66, 2004.

MOSER T, NEHER E: Rapid exocytosis in single chromaffin cells recorded from mouse adrenal slices. J Neurosci 17: 2314-2323, 1997. 
NEHER E: A comparison between exocytic control mechanisms in adrenal chromaffin cells and a glutamatergic synapse. Pflugers Arch 453: 261-268, 2006.

NEHER E, AUGUSTINE GJ: Calcium gradients and buffers in bovine chromaffin cells. $J$ Physiol 450: 273-301, 1992.

NEHER E, MARTY A: Discrete changes of cell-membrane capacitance observed under conditions of enhanced secretion in bovine adrenal chromaffin cells. Proc Natl Acad Sci U S A 79: 6712-6716, 1982.

NEHER E, SAKABA T: Multiple roles of calcium ions in the regulation of neurotransmitter release. Neuron 59: 861$872,2008$.

NEHER E, ZUCKER RS: Multiple calcium-dependent processes related to secretion in bovine chromaffin cells. Neuron 10: 21-30, 1993.

OBERHAUSER AF, ROBINSON IM, FERNANDEZ JM: Simultaneous capacitance and amperometric measurements of exocytosis: a comparison. Biophys J 71: 1131-1139, 1996.

OKAZAKI K, NIKI I, IINO S, KOBAYASHI S, HIDAKA H: A role of calcyclin, a $\mathrm{Ca}(2+)$-binding protein, on the $\mathrm{Ca}(2+)$-dependent insulin release from the pancreatic beta cell. J Biol Chem 269: 6149-6152, 1994.

PANG ZP, SÜDHOF TC: Cell biology of $\mathrm{Ca}^{2+}$-triggered exocytosis. Curr Opin Cell Biol 22: 496-505, 2010.

PAULMANN N, GROHMANN M, VOIGT JP, BERT B, VOWINCKEL J, BADER M, SKELIN M, JEVSEK M, FINK H, RUPNIK M, WALTHER DJ: Intracellular serotonin modulates insulin secretion from pancreatic beta-cells by protein serotonylation. PLoS Biol 7: e1000229, 2009.

RORSMAN P, RENSTROM E: Insulin granule dynamics in pancreatic beta cells. Diabetologia 46: 1029-1045, 2003.

ROSE T, EFENDIC S, RUPNIK M: $\mathrm{Ca}^{2+}$-secretion coupling is impaired in diabetic Goto Kakizaki rats. $J$ Gen Physiol 129: 493-508, 2007.

RUPNIK M, KREFT M, SIKDAR SK, GRILC S, ROMIH R, ZUPANČIČ G, MARTIN TFJ, ZOREC R: Rapid regulated dense-core vesicle exocytosis requires the CAPS protein. Proc Natl Acad Sci U S A 97: 5627-5632, 2000.

RUPNIK M, ZOREC R: Intracellular $\mathrm{Cl}^{-}$modulates $\mathrm{Ca}^{2+}$-induced exocytosis from rat melanotrophs through GTPbinding proteins. Pflugers Arch 431: 76-83, 1995.

SEDEJ S, ROSE T, RUPNIK M: cAMP increases $\mathrm{Ca}^{2+}$-dependent exocytosis through both PKA and Epac2 in mouse melanotrophs from pituitary tissue slices. $J$ Physiol 567 (Pt 3): 799-813, 2005.

SKELIN M, RUPNIK M: cAMP increases the sensitivity of exocytosis to $\mathrm{Ca}^{2+}$ primarily through protein kinase A in mouse pancreatic beta cells. Cell Calcium 49: 89-99, 2011.

SPEIER S, RUPNIK M: A novel approach to in situ characterization of pancreatic B-cells. Pflugers Arch 446: 553-558, 2003.

TAKAHASHI N, KADOWAKI T, YAZAKI Y, MIYASHITA Y, KASAI H: Multiple exocytotic pathways in pancreatic beta cells. $J$ Cell Biol 138, 55-64. 1997.

TERAOKA H, SUGAWARA T, NAKAZATO Y: Difference in the effectiveness of $\mathrm{Ca}(2+)$ to evoke catecholamine secretion between adrenaline- and noradrenaline-containing cells of bovine adrenal-medulla. J Neurochem $\mathbf{6 0}$ : 1936-1940, 1993.

THOMAS-REETZ AC, DE CAMILLI P: A role for synaptic vesicles in non-neuronal cells: clues from pancreatic beta cells and from chromaffin cells. FASEB $J$ 8: 209-216, 1994.

THOMAS P, WONG JG, LEE AK, ALMERS W: A low affinity $\mathrm{Ca}^{2+}$ receptor controls the final steps in peptide secretion from pituitary melanotrophs. Neuron 11: 93-104, 1993.

VARDJAN N, STENOVEC M, JORGACEVSKI J. KREFT M, ZOREC R: Subnanometer fusion pores in spontaneous exocytosis of peptidergic vesicles. $J$ Neurosci 27: 4737-4746, 2007.

VOETS T: Dissection of three $\mathrm{Ca}^{2+}$-dependent steps leading to secretion in chromaffin cells from mouse adrenal slices. Neuron 28: 537-545, 2000.

VOETS T, NEHER E, MOSER T: Mechanisms underlying phasic and sustained secretion in chromaffin cells from mouse adrenal slices. Neuron 23: 607-615, 1999.

WAN QF, DONG Y, YANG H, LOU X, DING J, XU T: Protein kinase activation increases insulin secretion by sensitizing the secretory machinery to $\mathrm{Ca}^{2+} . J$ Gen Physiol 124: 653-662, 2004.

YANG Y, GILLIS KD: A highly $\mathrm{Ca}^{2+}$-sensitive pool of granules is regulated by glucose and protein kinases in insulinsecreting INS-1 cells. J Gen Physiol 124: 641-651, 2004. 
YASEEN MA, PEDLEY KC, HOWELL SL: Regulation of insulin secretion from islets of Langerhans rendered permeable by electric discharge. Biochem $J$ 206: 81-87, 1982. 